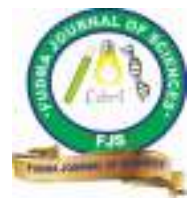

FUDMA Journal of Sciences (FJS)

ISSN online: $2616-1370$

ISSN print: 2645 - 2944

Vol. 4 No. 3, September, 2020, pp $406-415$

DOI: https://doi.org/10.33003/fjs-2020-0403-376

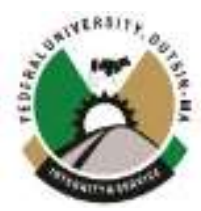

\title{
LOGARITHMIC AND PERCENTAGE REDUCTIONS OF BACTERIAL ISOLATES IN GALATEA PARADOXA TREATED WITH CITRUS AURANTIFOLIA AND NACL: PUBLIC HEALTH IMPLICATION AND NUTRITIONAL ASSESSMENT
}

\section{Okon Matthew Umanah, *Akinjogunla Olajide Joseph, Akang Inyene Akan, Akaka Blessing Christopher and Umoh Menyene Ime}

\author{
Department of Microbiology, Faculty of Science, University of Uyo, P.M.B. 1017, Uyo \\ Akwa Ibom State, Nigeria
}

*Corresponding Author's email: papajyde2000@yahoo.com, 08064069404

\begin{abstract}
Shell fishes constitute a vital source of food for humans due to its high nutritional values. Bacteriological and nutritional assessments of Galatea paradoxa treated with Citrus aurantifolia and $\mathrm{NaCl}$ were determined using bacteriological and analytical protocols. The results revealed a reduction from 4.845 to $2.301 \mathrm{Log}$ CFU/g in Total Heterotrophic Bacterial Counts (THBC) in G. paradoxa treated with $10 \% \mathrm{NaCl}$ for 5 mins. The G. paradoxa treated with $7.5 \% \mathrm{NaCl}$ for $5 \mathrm{~min}$ had a reduction in Total Coliform Counts (TCC) ranging from 3.903 to $2.398 \mathrm{Log}$ CFU/g, while Total Faecal Coliform Counts (TFC) in G. paradoxa treated with $5 \%$ and $10 \%$ for 10 min reduced by $99.99 \%$. There was $53.46 \%$ THBC reduction in G. paradoxa treated with $10 \%$ C. aurantifolia for $5 \mathrm{~min}$; THBC in G. paradoxa treated with $10 \%$ C. aurantifolia for $10 \mathrm{~min}$ reduced by $79.36 \%$; THBC in G. paradoxa treated with $10 \%$ equal concentrations of $\mathrm{NaCl}$ and C. aurantifolia decreased by $99.99 \%$ within 10 min, while TCC in G. paradoxa treated with $7.5 \%$ equal concentrations of $\mathrm{NaCl}$ and $C$. aurantifolia within $10 \mathrm{~min}$ of exposure had $99.99 \%$ decrease. The predominant survived bacterial genera in treated samples were Bacillus, Vibrio and Micrococcus. There was insignificant difference $(\mathrm{p} \geq 0.05)$ between the nutritional compositions of treated and untreated samples. This study showed that $G$. paradoxa could be treated with $C$. aurantifolia and $\mathrm{NaCl}$ so as to avert possible foodborne diseases associated with consumption of this aquatic food.
\end{abstract}

Keywords: Bacteriological, Citrus aurantifolia, $\mathrm{NaCl}$, Galatea paradoxa, Nutritional.

\section{INTRODUCTION}

An increase in population worldwide has resulted in a substantial increase in consumption of aquatic food such as Galatea paradoxa (Samya and Mohammed, 2006). Galatea paradoxa (Born 1778) are freshwater clams, bivalve and filter feeding mollusc that belong to order 'Veneroidea'; superfamily 'Tellinoidea' and family 'Donacidae' (Moses, 1990). These aquatic animals, without vertebral column, have two hinged calcareous shells that aid its protection and are endemic in West African countries such as Ghana, Nigeria and Cameroun (Etim and Brey, 1994; Villalobs and Elguezabel, 2001). The high nutritional values of shellfishes have triggered its increased consumption (Ekanem and Adegoke, 1995; Simopoulos, 2003). Galatea paradoxa constitute a vital source of food for humans due to its high protein content, low cholesterol content, significant amounts of omega-3-fatty acids (Ekpenyong et al., 2013), vitamins, iron, potassium, zinc, copper, manganese and selenium (Davies and Jamabo, 2016).

The G. paradoxa are a suitable bio-indicator of environmental pollution (Chiesa et al., 2018; Okon et al., 2020). They can accumulate human pathogenic organisms from sewage contaminated waters and also accumulate toxins in its soft tissues through feeding on toxic phytoplankton (Gram et al., 2002). The ingestion of contaminated soft tissues of G. paradoxa by humans may result in food-borne related diseases (Hathal et al., 2005). The soft tissue of $G$. paradoxa is consumed after frying, smoking, roasting, steaming or cooking (King, 2000; Villalobs and Elguezabel, 2001) and G. paradoxa also serves as a means of livelihood some dwellers in parts of Southern Nigeria.

Sodium chloride $(\mathrm{NaCl})$ is one of the most extensively used food additives as a preservative, enhancing the flavour and enzymatic activities responsible for organoleptic parameters (Cheng et al., 2003; Silva et al., 2003), and improving water adsorption which aids in inhibiting growth of spoilage and pathogenic organisms (Lawrence et al., 2003; Man, 2007). The reduction of water activity due to addition of salt and presence of ions exerts osmotic pressure effects on the microorganisms, thus, increase the shelf life of the processed food (Anbalagan et al., 2014). The inadequacy of $\mathrm{NaCl}$ as a sole preservative in ready-to-eat and other food products has necessitated its combination with other preservation processes such as addition of chemicals, drying and osmotic dehydration.

The Food Safety and Inspection Service of the United States Department of Agriculture has approved the use of lime (Citrus aurantifolia) juice as a natural antimicrobial agent having been recognized as safe for its application in food (Skrivanova et al., 2011). The juice of $C$. aurantifolia has been reported to reduce the growth of some bacteria in family Enterobacteriaceae and its antibacterial activities has attributed to its low $\mathrm{pH}$ that can penetrate the bacterial membranes (Davidson and Taylor, 2007; Bradley et al., 2011). However, there is a need to evaluate natural occurring organic compound that can be applied as post-harvest treatment to $G$. paradoxa. Consequently, this study determined the effect of citrus aurantifolia and $\mathrm{NaCl}$ singly and in combination on bacterial loads and nutritional quality of G. paradoxa. 


\section{MATERIALS AND METHODS}

\section{Collection of Samples}

Freshly harvested $G$. paradoxa were obtained from two major markets (Itam and Akpan Andem markets) in Uyo using sterile wide-mouth plastic containers and were transported to the Microbiology Laboratory, University of Uyo. The G. paradoxa was identified and confirmed by a Fish Taxonomist in the Department of Fisheries and Aquaculture, University of Uyo. Galatea paradoxa were extensively washed with sterile distilled water and rinsed with normal saline to remove all extraneous materials before shucking. The edible part was aseptically removed as described by APHA (1998) and was transferred into sterile containers for bacteriological and nutritional analyses.

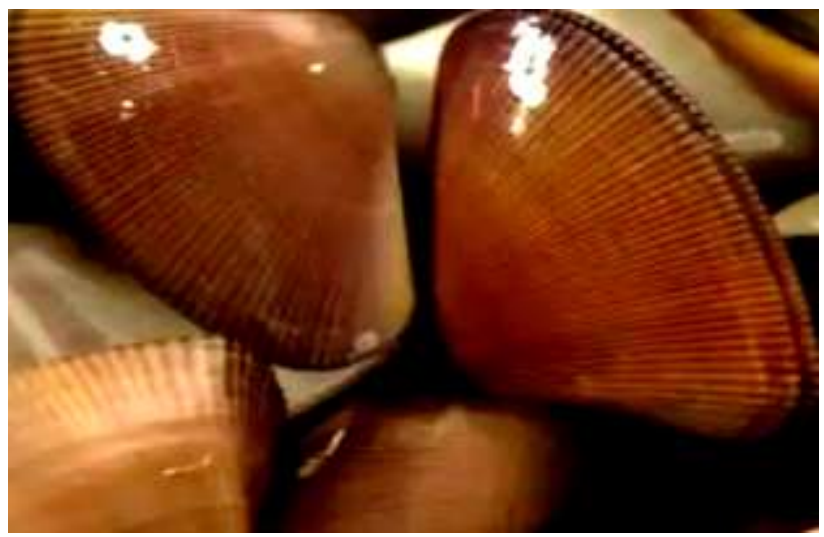

Fig 1: G. paradoxa

\section{Bacteriological Analysis of Samples}

Ten (10) grams of each fleshy blended parts of G. paradoxa was aseptically suspended into $90 \mathrm{ml}$ sterile distilled water, vigorously shaken to dislodge adhered bacteria and ten-fold serial dilutions were made to obtain dilutions $10^{-1}$ to $10^{-3}$. One (1) $\mathrm{mL}$ of aliquot was pour-plated in triplicate onto each plate of Nutrient Agar (NA), MacConkey Agar (MCA), Eosine Methylene Blue Agar (EMB) and the plates were aerobically incubated at $37^{\circ} \mathrm{C}$ for $24 \mathrm{hr}$. After incubation, colonies on plates were counted and multiplied by the dilution to obtain the Total Heterotrophic Bacterial Counts (THBC), Total Coliform Counts (TCC) and Total Faecal Coliform Counts (TFC), respectively. The discrete colonies were sub-cultured onto freshly prepared NA plates and aerobically incubated at $37^{\circ} \mathrm{C}$ for $24 \mathrm{hr}$. The pure cultures of isolates were streaked onto NA slant, incubated at $37^{\circ} \mathrm{C}$ and stored in a refrigerator at $4{ }^{\circ} \mathrm{C}$ for characterization and identification. All isolates were Gram stained and subjected to convectional biochemical tests (Holt et al., 1994).

Effect of $C$. aurantifolia and $\mathrm{NaCl}$ on the Bacterial Loads of $G$. paradoxa

The $C$. aurantifolia juice was extracted using the method of Ndelekwute and Enyenihi (2017). Fleshy part of G. paradoxa was suspended into sterile conical flasks containing varied concentrations $(2.5 \%, 5.0 \%, 7.5 \%$ and $10 \%)$ of $\mathrm{NaCl}$ and $C$. aurantifolia, respectively. The contents of sterile conical flasks were allowed to stand for 5 and $10 \mathrm{~min}$, respectively. Thereafter, $10 \mathrm{~g}$ of each fleshy part was blended, separately suspended into $90 \mathrm{ml}$ sterile distilled water, vigorously shaken to dislodge adhered bacteria and dilutions were made to obtain $10^{-1}$ and $10^{-3}$. One (1) $\mathrm{ml}$ of the aliquot was pour-plated in triplicate onto each plate of NA, MCA, EMB and incubated aerobically at $37{ }^{\circ} \mathrm{C}$ for $24 \mathrm{hr}$. The same procedure was carried out for combination of $\mathrm{NaCl}$ and $C$. aurantifolia at ratio of $1: 1(\mathrm{vol} / \mathrm{vol})$. The same procedures were carried on control ( $G$. paradoxa untreated with $\mathrm{NaCl}$ and $C$. aurantifolia). After incubation, the bacterial counts were recorded and mean, standard deviations were appropriately calculated.

\section{Proximate Analysis of G. paradoxa treated with $\mathrm{NaCl}$ and Citrus aurantifolia}

The moisture, lipid and ash contents of fleshy part of G. paradoxa samples were carried out using the methods of AOAC (2005). The fibre and protein contents were obtained by Kjeldahl's procedure and subsequently converted to crude protein by multiplying the values obtained with a protein conversion factor of 6.25. The energy content was calculated as follows: Energy Kcal 100g $=$ (crude lipid $\mathrm{x} 8)+($ crude protein $\mathrm{x} 2)+(\mathrm{CHO} \times \mathrm{x} 4)$, where $\mathrm{CHO}$ was carbohydrate contents of $G$. paradoxa. All determinations were done in triplicates and values obtained were expressed as mean \pm standard deviation.

\section{Statistical Analysis}

The Statistical Package for Social Sciences (IBM SPSS Version 22.0) was used for data analysis. The significant difference ( $\mathrm{p} \leq$ 0.05 ) between the nutritional compositions of G. paradoxa treated with $\mathrm{NaCl}$ / Citrus aurantifolia and the untreated G. paradoxa were determined using one-way Analysis of Variance (ANOVA).

\section{RESULTS}

The logarithmic and percentage reductions of bacterial loads in $G$. paradoxa treated with $\mathrm{NaCl}$ are presented in Table 1 . The results revealed a THBC reduction in $G$. paradoxa treated with $10 \% \mathrm{NaCl}$ for 5 mins from 4.845 to $2.301 \mathrm{Log} \mathrm{CFU} / \mathrm{g}$, while THBC in $G$. paradoxa samples treated with $10 \% \mathrm{NaCl}$ for 5 mins decreased from 4.845 to $1.146 \mathrm{Log}$ CFU/g. The G. paradoxa treated with $7.5 \%$ $\mathrm{NaCl}$ for $5 \mathrm{~min}$ had a TCC reduction ranging from 3.903 to 2.398 $\log \mathrm{CFU} / \mathrm{g} ; G$. paradoxa treated with $7.5 \%$ at $10 \mathrm{~min}$ had a reduction in TCC (3.903 to $1.041 \mathrm{Log}$ CFU/g), while TFC in $G$. paradoxa treated with $5 \%$ and $10 \%$ for 10 min reduced by $99.99 \%$ (Table 1)

The logarithmic and percentage reductions of bacterial loads in $G$. paradoxa treated with $C$. aurantifolia are presented in Table 2 . The 
results showed $53.46 \%$ THBC reduction in G. paradoxa treated with $10 \%$ C. aurantifolia for $5 \mathrm{~min}$, while THBC in G. paradoxa treated with $10 \%$ C. aurantifolia for 10 min reduced by $79.36 \%$. G. paradoxa treated with $7.5 \% \mathrm{C}$. aurantifolia for both $5 \mathrm{~min}$ and 10 min did not have TCC, respectively; while $G$. paradoxa treated with $7.5 \%$ C. aurantifolia for 5 min had no TFC (Table 2).

The logarithmic and percentage reductions of bacterial loads in $G$. paradoxa treated with combination of $\mathrm{NaCl}$ and $C$. aurantifolia are presented in Table 3. The THBC in G. paradoxa sample treated with equal concentrations $(10 \%)$ of $\mathrm{NaCl}$ and $C$. aurantifolia decreased by $99.99 \%$ within 10 min of exposure, while TCC and TFC in $G$. paradoxa treated with equal concentrations (vol / vol) of $7.5 \%$ ( $\mathrm{NaCl}$ and C. aurantifolia) within $10 \mathrm{~min}$ of exposure had $99.99 \%$ decrease (Table 3).

The trends of occurrence of bacterial isolates from G. paradoxa treated with $\mathrm{NaCl}$ and $C$. aurantifolia singly and in combination are shown in Table 4. The results revealed that B. subtilis, S. aureus, $M$. varians, $E$. coli, $K$. pneumoniae, $V$. cholerae and $P$. aeruginosa survived in G. paradoxa treated with $5 \%$ of $\mathrm{NaCl}$ or $C$. aurantifolia within 5 min of exposure. Although, B. subtilis were predominant in all the treated samples, but combination of $10 \%$ equal volume (vol / vol) of C. aurantifolia and $\mathrm{NaCl}$ killed the bacterial isolate.

The comparative analyses of proximate compositions of $G$. paradoxa treated with $\mathrm{NaCl}$ and $C$. aurantifolia singly and in combination are presented in Table 5. The highest moisture content of $67 \pm 1 \%$ was obtained from sample $C_{d}$ (control), followed by sample $\mathrm{Cb}_{\mathrm{b}}(G$. paradoxa treated with $10 \%$ C. aurantifolia $)$ with 62 $\pm 1 \%$, while the lowest moisture content of $50 \pm 2 \%$ was obtained from sample $\mathrm{C}_{\mathrm{c}}(G$. paradoxa treated with equal volume of $10 \%$ $\mathrm{NaCl}$ and $10 \%$ C. aurantifolia). The ash content was highest in sample $\mathrm{C}_{\mathrm{d}}$ with $3.950 \pm 0.01 \%$ and lowest in sample $\mathrm{C}_{\mathrm{c}}$ with $3.75 \pm$ $0.03 \%$. Samples $\mathrm{C}_{\mathrm{c}}$ and $\mathrm{C}_{\mathrm{a}}$ had the lowest fibre $(0.023 \pm 0.02 \%)$ and protein $(32.10 \pm 0.25 \%)$ content respectively, while the highest fibre $(0.045 \pm 0.01 \%)$ and protein $(33.229 \pm 0.10 \%)$ content was obtained in sample $C_{d}$. The crude lipid was highest in sample $C_{a}$ with $1.360 \pm 0.02 \%$ and was lowest in sample $\mathrm{C}_{\mathrm{c}}(1.290 \pm 0.001 \%)$. The total carbohydrate was highest in sample $\mathrm{C}_{a}(62.700 \pm 0.11 \%)$ and was lowest in sample $\mathrm{C}_{\mathrm{c}}(58.606 \pm 0.20 \%)$. There was no statistically significant difference $(\mathrm{p}>0.05)$ between the nutritional compositions of G. paradoxa treated with $\mathrm{NaCl} /$ Citrus aurantifolia and the untreated G. paradoxa (Table 5).

Table 1. Logarithmic and Percentage Reductions of Bacterial Loads in Galatea paradoxa Treated with NaCl

\begin{tabular}{|c|c|c|c|c|c|c|c|}
\hline $\begin{array}{l}\text { Exposure } \\
\text { (mins) }\end{array}$ & Time & $\begin{array}{l}\text { Microbial } \\
\text { Group }\end{array}$ & $\begin{array}{c}\text { Concentration } \\
(\%)\end{array}$ & $\begin{array}{l}\text { Plate Counts } \\
\text { (CFU/g) }\end{array}$ & $\begin{array}{c}\log \\
(\mathrm{CFU} / \mathrm{g})\end{array}$ & $\begin{array}{c}\% \\
\text { Reduction }\end{array}$ & Log reduction \\
\hline \multirow{15}{*}{\multicolumn{2}{|c|}{5}} & \multirow{5}{*}{ THBC } & 0 & $7.0 \pm 0.4 \times 10^{4}$ & 4.845 & NA & NA \\
\hline & & & 2.5 & $6.4 \pm 0.7 \times 10^{4}$ & 4.806 & 0.80 & 0.04 \\
\hline & & & 5.0 & $4.5 \pm 0.1 \times 10^{3}$ & 3.653 & 24.60 & 1.19 \\
\hline & & & 7.5 & $3.0 \pm 0.7 \times 10^{2}$ & 2.447 & 48.88 & 2.37 \\
\hline & & & 10 & $2.0 \pm 0.3 \times 10^{2}$ & 2.301 & 52.51 & 2.54 \\
\hline & & \multirow{5}{*}{ TCC } & 0 & $8.0 \pm 0.1 \times 10^{3}$ & 3.903 & NA & NA \\
\hline & & & 2.5 & $3.9 \pm 0.3 \times 10^{3}$ & 3.591 & 7.994 & 0.31 \\
\hline & & & 5.0 & $5.6 \pm 0.8 \times 10^{2}$ & 2.748 & 29.59 & 1.16 \\
\hline & & & 7.5 & $2.5 \pm 0.5 \times 10^{2}$ & 2.398 & 38.66 & 1.51 \\
\hline & & & 10 & NG & NA & $\geq 99.99$ & 3.90 \\
\hline & & \multirow{5}{*}{ TFC } & 0 & $3.0 \pm 0.7 \times 10^{2}$ & 2.477 & NA & NA \\
\hline & & & 2.5 & $2.1 \pm 0.2 \times 10^{2}$ & 2.322 & 6.258 & 0.16 \\
\hline & & & 5.0 & $1.5 \pm 0.4 \times 10^{2}$ & 1.176 & 52.52 & 1.30 \\
\hline & & & 7.5 & NG & NA & $\geq 99.99$ & 2.48 \\
\hline & & & 10 & $\mathrm{NG}$ & NA & $\geq 99.99$ & 2.48 \\
\hline \multirow{15}{*}{\multicolumn{2}{|c|}{10}} & \multirow{5}{*}{ THBC } & 0 & $7.0 \pm 0.4 \times 10^{4}$ & 4.845 & NA & NA \\
\hline & & & 2.5 & $5.2 \pm 0.4 \times 10^{4}$ & 4.716 & 2.663 & 0.13 \\
\hline & & & 5.0 & $3.9 \pm 0.3 \times 10^{2}$ & 3.591 & 25.88 & 1.25 \\
\hline & & & 7.5 & $2.1 \pm 0.2 \times 10^{2}$ & 2.322 & 52.07 & 2.52 \\
\hline & & & 10 & $1.4 \pm 0.1 \times 10^{1}$ & 1.146 & 76.35 & 3.70 \\
\hline & & \multirow{5}{*}{ TCC } & 0 & $8.0 \pm 0.1 \times 10^{3}$ & 3.903 & NA & NA \\
\hline & & & 2.5 & $4.5 \pm 0.1 \times 10^{2}$ & 2.653 & 32.03 & 1.25 \\
\hline & & & 5.0 & $2.1 \pm 0.2 \times 10^{2}$ & 2.322 & 40.50 & 1.58 \\
\hline & & & 7.5 & $1.1 \pm 0.0 \times 10^{1}$ & 1.041 & 73.33 & 2.86 \\
\hline & & & 10 & NG & NA & $\geq 99.99$ & 3.90 \\
\hline & & \multirow{5}{*}{ TFC } & 0 & $3.0 \pm 0.7 \times 10^{2}$ & 2.477 & NA & NA \\
\hline & & & 2.5 & $1.0 \pm 0.0 \times 10^{2}$ & 1.000 & 59.63 & 1.48 \\
\hline & & & 5.0 & NG & NA & $\geq 99.99$ & 2.30 \\
\hline & & & 7.5 & NG & NA & $\geq 99.99$ & 2.30 \\
\hline & & & 10 & $\mathrm{NG}$ & NA & $\geq 99.99$ & 2.30 \\
\hline
\end{tabular}

Keys: THBC: Total Heterotrophic Bacterial Counts; TCC: Total Coliform Counts; TFC: Total Faecal Coliforn Counts; NG: No Growth; NA: Not Applicable CFU: Colony Forming Units; Log: Logarithmic. 
Table 2 Logarithmic and Percentage Reductions of Bacterial Loads in Galatea paradoxa Treated with Citrus aurantifolia

\begin{tabular}{|c|c|c|c|c|c|c|}
\hline $\begin{array}{l}\text { Exposure Time } \\
\text { (mins) }\end{array}$ & $\begin{array}{l}\text { Microbial } \\
\text { Group }\end{array}$ & Concentration (\%) & $\begin{array}{l}\text { Plate Counts } \\
\text { (CFU/g) }\end{array}$ & $\begin{array}{c}\text { Log } \\
(\mathrm{CFU} / \mathrm{g})\end{array}$ & $\begin{array}{c}\% \\
\text { Reduction }\end{array}$ & Log reduction \\
\hline \multirow[t]{15}{*}{ 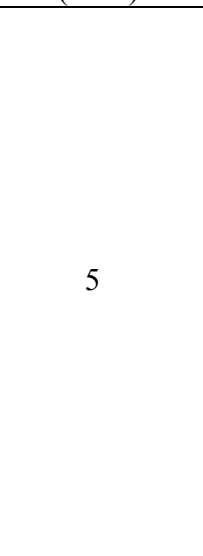 } & \multirow{5}{*}{ THBC } & 0 & $7.0 \pm 0.4 \times 10^{4}$ & 4.845 & NA & NA \\
\hline & & 2.5 & $4.5 \pm 0.1 \times 10^{4}$ & 4.653 & 3.96 & 0.04 \\
\hline & & 5.0 & $3.5 \pm 0.8 \times 10^{3}$ & 3.544 & 26.85 & 1.30 \\
\hline & & 7.5 & $2.5 \pm 0.3 \times 10^{2}$ & 2.398 & 50.51 & 2.45 \\
\hline & & 10 & $1.8 \pm 0.7 \times 10^{2}$ & 2.255 & 53.46 & 2.59 \\
\hline & \multirow{5}{*}{ TCC } & 0 & $8.0 \pm 0.1 \times 10^{3}$ & 3.903 & NA & NA \\
\hline & & 2.5 & $3.3 \pm 0.2 \times 10^{3}$ & 3.591 & 9.839 & 0.38 \\
\hline & & 5.0 & $2.8 \pm 0.4 \times 10^{2}$ & 2.748 & 37.30 & 1.46 \\
\hline & & 7.5 & $1.2 \pm 0.7 \times 10^{1}$ & 1.079 & 72.35 & 2.82 \\
\hline & & 10 & $\mathrm{NG}$ & NA & $\geq 99.99$ & 3.90 \\
\hline & \multirow{5}{*}{ TFC } & 0 & $3.0 \pm 0.7 \times 10^{2}$ & 2.477 & NA & NA \\
\hline & & 2.5 & $1.4 \pm 0.3 \times 10^{2}$ & 2.146 & 13.36 & 0.16 \\
\hline & & 5.0 & $1.0 \pm 0.0 \times 10^{1}$ & 1.000 & 59.63 & 1.30 \\
\hline & & 7.5 & $\mathrm{NG}$ & NA & $\geq 99.99$ & 2.48 \\
\hline & & 10 & NG & NA & $\geq 99.99$ & 2.48 \\
\hline \multirow{15}{*}{10} & \multirow{5}{*}{ THBC } & 0 & $7.0 \pm 0.4 \times 10^{4}$ & 4.845 & NA & NA \\
\hline & & 2.5 & $2.0 \pm 0.4 \times 10^{3}$ & 3.301 & 31.87 & 1.54 \\
\hline & & 5.0 & $2.4 \pm 0.2 \times 10^{2}$ & 2.380 & 50.88 & 2.47 \\
\hline & & 7.5 & $2.0 \pm 0.4 \times 10^{1}$ & 1.301 & 73.15 & 3.54 \\
\hline & & 10 & $1.0 \pm 0.0 \times 10^{1}$ & 1.000 & 79.36 & 3.85 \\
\hline & \multirow{5}{*}{ TCC } & 0 & $8.0 \pm 0.1 \times 10^{3}$ & 3.903 & NA & NA \\
\hline & & 2.5 & $2.8 \pm 0.4 \times 10^{2}$ & 2.447 & 37.30 & 1.46 \\
\hline & & 5.0 & $1.0 \pm 0.0 \times 10^{1}$ & 1.000 & 74.38 & 2.90 \\
\hline & & 7.5 & NG & NA & $\geq 99.99$ & \multirow{2}{*}{$3.90^{3.90}$} \\
\hline & & 10 & NG & NA & $\geq 99.99$ & \\
\hline & \multirow{5}{*}{ TFC } & 0 & $3.0 \pm 0.7 \times 10^{2}$ & 2.477 & NA & NA \\
\hline & & 2.5 & NG & NA & $\geq 99.99$ & 2.48 \\
\hline & & 5.0 & NG & NA & $\geq 99.99$ & 2.48 \\
\hline & & 7.5 & NG & NA & $\geq 99.99$ & 2.48 \\
\hline & & 10 & NG & NA & $\geq 99.99$ & 2.48 \\
\hline
\end{tabular}

Keys: THBC: Total Heterotrophic Bacterial Counts; TCC: Total Coliform Counts; TFC:

Total Faecal Coliform Counts; NG: No Growth; NA: Not Applicable; CFU: Colony Forming Units; Log: Logarithmic. 
Table 3: Logarithmic and Percentage Reductions of Bacterial Isolates in Galatea paradoxa Treated with $\mathrm{NaCl}$ and Citrus aurantifolia

\begin{tabular}{|c|c|c|c|c|c|c|c|}
\hline $\begin{array}{l}\begin{array}{l}\text { Exposure } \\
\text { (mins) }\end{array} \\
\end{array}$ & Time & $\begin{array}{r}\text { Microbial } \\
\text { Group }\end{array}$ & Concentration (\%) & Plate Counts (CFU/g) & $\log (\mathrm{CFU} / \mathrm{g})$ & $\%$ Reduction & $\begin{array}{c}\text { Log } \\
\text { reduction }\end{array}$ \\
\hline \multirow{15}{*}{ (17inis) } & \multirow{5}{*}{\multicolumn{2}{|c|}{ THBC }} & 0 & $7.0 \pm 0.3 \times 10^{4}$ & 4.845 & NA & NA \\
\hline & & & 2.5 & $3.9 \pm 0.1 \times 10^{4}$ & 4.591 & 5.243 & 0.25 \\
\hline & & & 5.0 & $2.1 \pm 0.1 \times 10^{3}$ & 3.322 & 31.43 & 1.52 \\
\hline & & & 7.5 & $1.1 \pm 0.7 \times 10^{2}$ & 2.041 & 57.87 & 2.80 \\
\hline & & & 10 & $1.0 \pm 0.3 \times 10^{2}$ & 2.000 & 58.72 & 2.85 \\
\hline & \multirow{5}{*}{\multicolumn{2}{|c|}{ TCC }} & 0 & $8.0 \pm 0.4 \times 10^{3}$ & 3.903 & NA & NA \\
\hline & & & 2.5 & $4.5 \pm 0.2 \times 10^{2}$ & 2.653 & 32.03 & 1.25 \\
\hline & & & 5.0 & $1.0 \pm 0.3 \times 10^{2}$ & 2.000 & 48.76 & 1.90 \\
\hline & & & 7.5 & $\mathrm{NG}$ & NA & $\geq 99.99$ & 3.90 \\
\hline & & & 10 & NG & NA & $\geq 99.99$ & 3.90 \\
\hline & \multirow{5}{*}{\multicolumn{2}{|c|}{ TFC }} & 0 & $3.0 \pm 0.7 \times 10^{2}$ & 2.477 & NA & NA \\
\hline & & & 2.5 & $\mathrm{NG}$ & NA & $>99.99$ & 2.48 \\
\hline & & & 5.0 & NG & NA & $\geq 99.99$ & 2.48 \\
\hline & & & 7.5 & NG & NA & $\geq 99.99$ & 2.48 \\
\hline & & & 10 & NG & NA & $\geq 99.99$ & 2.48 \\
\hline \multirow{15}{*}{10} & \multirow{5}{*}{\multicolumn{2}{|c|}{ THBC }} & 0 & $7.0 \pm 0.3 \times 10^{4}$ & 4.845 & NA & NA \\
\hline & & & 2.5 & $1.8 \pm 0.4 \times 10^{3}$ & 3.255 & 32.62 & 1.59 \\
\hline & & & 5.0 & $1.6 \pm 0.6 \times 10^{2}$ & 2.204 & 54.51 & 2.64 \\
\hline & & & 7.5 & $1.0 \pm 0.3 \times 10^{2}$ & 2.000 & 58.72 & 2.85 \\
\hline & & & 10 & NG & NA & $\geq 99.99$ & 4.85 \\
\hline & \multirow{5}{*}{\multicolumn{2}{|c|}{ TCC }} & 0 & $8.0 \pm 0.4 \times 10^{3}$ & 3.903 & NA & NA \\
\hline & & & 2.5 & NG & NA & $\geq 99.99$ & 3.90 \\
\hline & & & 5.0 & NG & NA & $\geq 99.99$ & 3.90 \\
\hline & & & 7.5 & NG & NA & $\geq 99.99$ & 3.90 \\
\hline & & & 10 & NG & NA & $\geq 99.99$ & 3.90 \\
\hline & \multirow{5}{*}{\multicolumn{2}{|c|}{ TFC }} & 0 & $3.0 \pm 0.7 \times 10^{2}$ & 2.477 & NA & NA \\
\hline & & & 2.5 & NG & NA & $\geq 99.99$ & 2.48 \\
\hline & & & 5.0 & NG & NA & $\geq 99.99$ & 2.48 \\
\hline & & & 7.5 & NG & NA & $\geq 99.99$ & 2.48 \\
\hline & & & 10 & NG & NA & $\geq 99.99$ & 2.48 \\
\hline
\end{tabular}

Keys: THBC: Total Heterotrophic Bacterial Counts; TCC: Total Coliform Counts; TFC: Total Faecal Coliform Counts; NG: No Growth; NA: Not Applicable; CFU: Colony Forming Unit; Log: Logarithmic. 
Table 4: Occurrence of Bacterial Isolates in G. paradoxa treated with $\mathrm{NaCl}$ and C. aurantifolia

\begin{tabular}{|c|c|c|c|c|c|c|c|c|c|c|c|c|c|c|}
\hline \multirow[t]{2}{*}{ Bacterial Isolates } & \multirow{2}{*}{$\begin{array}{l}\text { UTD } \\
\quad 0 \%\end{array}$} & \multicolumn{2}{|c|}{$\begin{array}{c}\mathrm{A} \\
(5 \mathrm{mins}) \\
\end{array}$} & \multicolumn{2}{|c|}{$\begin{array}{c}\mathrm{A} \\
(10 \mathrm{mins}) \\
\end{array}$} & \multicolumn{2}{|c|}{$\begin{array}{c}\mathrm{B} \\
(5 \mathrm{mins}) \\
\end{array}$} & \multicolumn{2}{|c|}{$\begin{array}{c}\text { B } \\
(10 \text { mins }) \\
\end{array}$} & \multicolumn{2}{|c|}{$\begin{array}{c}A+B \\
(5 \text { mins })\end{array}$} & \multicolumn{2}{|c|}{$\begin{array}{c}\mathrm{A}+\mathrm{B} \\
(10 \text { mins })\end{array}$} & \multirow{2}{*}{$\begin{array}{c}\text { Tota } \\
\text { No }\end{array}$} \\
\hline & & $5 \%$ & $10 \%$ & $5 \%$ & $10 \%$ & $5 \%$ & $10 \%$ & $5 \%$ & $10 \%$ & $5 \%$ & $10 \%$ & $5 \%$ & $10 \%$ & \\
\hline B. subtilis & + & + & + & + & + & + & + & + & + & + & + & - & - & 11 \\
\hline S. aureus & + & + & - & + & - & + & - & + & - & + & - & - & - & 6 \\
\hline M. varians & + & + & + & + & - & + & - & + & - & + & - & - & - & 7 \\
\hline S. enterica & + & - & - & - & - & + & - & + & - & - & - & - & - & 3 \\
\hline S. pyogenes & + & - & - & - & - & + & - & - & - & - & - & - & - & 2 \\
\hline E. coli & + & + & - & + & - & + & - & + & - & + & - & - & - & 6 \\
\hline K. pneumoniae & + & + & - & - & - & + & - & + & - & - & - & - & - & 4 \\
\hline E. aerogenes & + & - & - & - & - & - & - & - & - & - & - & - & - & 1 \\
\hline V. cholerae & + & + & - & + & - & + & - & + & - & + & - & + & - & 7 \\
\hline E. faecium & + & - & - & - & - & + & + & - & - & - & - & - & - & 3 \\
\hline P. aeruginosa & + & + & - & + & - & + & - & + & - & - & - & - & - & 5 \\
\hline Total & 11 & 7 & 2 & 6 & 1 & 10 & 2 & 8 & 1 & 5 & 1 & 1 & 0 & 55 \\
\hline
\end{tabular}

Keys: UTD: Untreated; A: NaCl; B: Citrus aurantifolia; A + B: Sodium Chloride + Citrus aurantifolia; +: Present; -: Absent. 
Table 5: Proximate Compositions of G. paradoxa treated with $\mathrm{NaCl}$ and Citrus aurantifolia

\begin{tabular}{|c|c|c|c|c|c|c|c|c|}
\hline \multirow[b]{2}{*}{ Sample } & \multirow[b]{2}{*}{ Treatment } & \multicolumn{6}{|c|}{ Percentage $/ \mathrm{mm} \pm$ S.D } & \multirow[b]{2}{*}{ Calorie Value (kcal) } \\
\hline & & $\begin{array}{c}\text { Moisture } \\
\text { Content }\end{array}$ & $\begin{array}{c}\text { Ash } \\
\text { Content }\end{array}$ & Fiber Content & $\begin{array}{c}\text { Crude } \\
\text { Lipid }\end{array}$ & Crude Protein & $\begin{array}{l}\text { Total } \\
\text { CHO }\end{array}$ & \\
\hline $\mathrm{C}_{\mathrm{a}}$ & $\mathrm{NaCl}$ & $61 \pm 2$ & $3.800 \pm 0.01$ & $0.040 \pm 0.01$ & $1.360 \pm 0.002$ & $32.100 \pm 0.25$ & $62.700 \pm 0.11$ & $391.468 \pm 0.001$ \\
\hline $\mathrm{C}_{\mathrm{b}}$ & C. aurantifolia & $62 \pm 1$ & $3.800 \pm 0.02$ & $0.041 \pm 0.01$ & $1.322 \pm 0.000$ & $32.222 \pm 0.22$ & $62.615 \pm 0.15$ & $391.228 \pm 0.002$ \\
\hline $\mathrm{C}_{\mathrm{c}}$ & $\begin{array}{c}\mathrm{NaCl}+ \\
\text { C. aurantifolia }\end{array}$ & $50 \pm 2$ & $3.750 \pm 0.03$ & $0.023 \pm 0.02$ & $1.290 \pm 0.001$ & $32.631 \pm 0.15$ & $58.606 \pm 0.20$ & $376.558 \pm 0.000$ \\
\hline $\mathrm{C}_{\mathrm{d}}$ & Control & $67 \pm 1$ & $3.950 \pm 0.01$ & $0.045 \pm 0.01$ & $1.320 \pm 0.002$ & $33.229 \pm 0.10$ & $61.951 \pm 0.30$ & $392.600 \pm 0.004$ \\
\hline
\end{tabular}

Each value represents the means of triplicate and standard deviation. CHO: Carbohydrate, ANOVA ( $p>0.05)$ 


\section{DISCUSSION}

Even though shellfishes, $G$. paradoxa, are substantially nutritious and have become an increasingly significant source of inexpensive proteins and other nutrients essential for maintenance of healthy body of a large section of world population, nevertheless, shellfishes harbour some pathogenic microorganisms attributable to poor hygienic conditions of the water bodies from where they are obtained (Adebayo-tayo et al., 2006; Oranusi et al. 2018).

In our study, a high THBC, TCC and FCC were obtained from $G$. paradoxa and these high bacterial loads substantiated the results of Ekanem and Adegoke (1995) and Oranusi et al. (2018) who discretely observed unacceptable bacterial loads in shell fishes. The high bacterial loads from $G$. paradoxa not treated with $\mathrm{NaCl}$ and $C$. aurantifolia in our study conform with the findings of Antai (1998) and Tonbarapagha et al. (2018) who obtained high microbial loads in shell fishes, but these findings contradicted the report of Udoh et al. (2017) who reported low bacterial loads from G. paradoxa in Cross River, Nigeria. Our findings showed that bacterial loads from G. paradoxa in Uyo, Akwa Ibom State, exceeded the acceptable limits for shellfishes as specified by FDA (1991) and ICMSF (2005). The high bacterial loads in the shell fishes, $G$. paradoxa, could be attributed to poor handling and processing in the markets (Odu et al., 2010; Akinjogunla et al., 2011).

In this study, logarithmic and percentage reductions in bacterial loads (THBC, TCC and TFC) in G. paradoxa treated with different concentrations of $\mathrm{NaCl}$ and $C$. aurantifolia singly or in combination for $\geq 10$ mins were obtained. The decrease in logarithmic and percentage reductions of bacterial loads in $G$. paradoxa treated with different concentrations (5 to $10 \%$ ) of $\mathrm{NaCl}$ agrees with Soyiri et al. (2008) and Anbalagan et al. (2014) who reported that $\mathrm{NaCl}$ concentrations between 7.5 and $10 \%$ eliminated all pathogenic bacteria from shell fishes. A medium containing $10 \% \mathrm{NaCl}$ has been reported as unfavourable medium for proliferation of pathogenic microorganisms (Onyeagba and Isu, 2006; Anbalagan et al. 2014). Similarly, studies have showed that $\mathrm{NaCl}$ removed water from food products by osmosis and as $\mathrm{NaCl}$ content in food increased its water content also decreased, thus, leading to plasmolysis of cell walls of pathogenic micro-organisms (Anbalagan et al. 2014; Orjimelukwe et al. 2017). This study revealed $79.36 \%$ THBC reduction in G. paradoxa treated with $10 \%$ C. aurantifolia for $10 \mathrm{~min}$. The reduction in bacterial loads to an acceptable level for human consumption in our study corroborated the findings of Rodrigues et al. (2000) and similarly agrees with the results of Mata et al. (1994) who reported extinction of some bacterial isolates in acidic medium containing lime (C. aurantifolia) juice.

The eleven bacterial genera obtained from $G$ paradoxa not treated with $\mathrm{NaCl}$ and C. aurantifolia were Staphylococcus, Micrococcus, Salmonella, Streptococcus, Escherichia, Klebsiella, Bacillus, Enterobacter, Vibrio, Enterococcus and Pseudomonas. The isolation of $S$. pyogenes, $V$. cholerae, $E$. coli, $S$. enterica and $S$. aureus in our study substantiated the reports of Udoh et al. (2017) who obtained these bacterial isolates from $G$ paradoxa in Cross River, Nigeria.
Our findings revealed $33.229 \%$ protein content in untreated $G$. paradoxa (control) and this value was lower than $47.0 \%$ obtained by Ehigiator and Akise (2016) in Delta State, but our findings agrees with Ivon and Eyo (2018) who reported $32.10 \%$ protein content in G. paradoxa from Calabar River, Nigeria. The moisture content in G. paradoxa was high in this study and this was in conformity with Zhu and Bai (2007). The high moisture content in shellfish has been attributed to the quantity of water absorbed into their cells from the external environment (Davies and Jamabo, 2016). A high ash content was discretely obtained from the untreated and G. paradoxa treated with $\mathrm{NaCl}$ and $C$. aurantifolia, and this concurs with results of Adeleke and Odedeji (2010). The ash content greater than $0.5 \%$ has been reported as an indication of good mineral content in food (Adeleke and Odedeji, 2010).

\section{CONCLUSION}

This study showed that $G$. paradoxa, harboured some pathogenic bacteria of public interest and its treatment with equal concentration ( $\mathrm{vol} / \mathrm{vol})$ of $10 \%$ C. aurantifolia and $\mathrm{NaCl}$ singly or in combination for 10 min holding time will avert possible foodborne diseases associated with consumption of this aquatic food.

\section{REFERENCES}

Adebayo-Tayo, B.C., Onilude, A. A., Ogunjobi, A. A. and Adeoye, D. O. (2006). Bacteriological and proximate analysis of periwinkles from two different creeks in Nigeria. World Applied Science Journal, 1(2): 87 - 91.

Adeleke, R. O. and Odedeji, J. O. (2010). Functional properties of wheat and sweet potato flour blends. Pakistan Journal of Nutrition, 9: $535-538$.

Akinjogunla, O. J., Inyang, C. U. and Akinjogunla, V. F. (2011). Bacterial species associated with anatomical parts of fresh and smoked Bonga fish (Ethmalosa fimbriata): Prevalence of cephalosporins. Research Journal of Microbiology, 6(1):87- 97.

Anbalagan, M., Ganesh Prabu, P., Krishnaveni, R. E. and Manivannan, S. (2014). Effect of sodium chloride $(\mathrm{NaCl})$ on the bacterial load in chicken, mutton and beef meat samples in relation to meat spoilage. International Journal of Research in Zoology, 4 (1): 1 - 5.

Antai, S. P. (1998). Study of the microbial flora of Nigeria mussel species. International Journal of Food Microbiology, 6: $259-261$.

AOAC (2005). Official Method of Analysis (18th ed). Association of Official Analytical Chemist International, Maryland, USA. 876p.

APHA (American Public Health Association). (1998). Standard methods for the examination of water and wastewater. 16th Edition, Washington D.C.

Bradley, E. M., Williams, J. B., Schilling, M. W., Coggin, P. C and Crist, C. (2011). Effects of sodium lactate and acetic acid preservatives on the quality and sensory characteristics of hot- 
boned pork sausage patties. Meat Science, 88: 145 - 150.

Chiesa, L. M., Nobile, M., Malandra, R., Pessina, D and Panseri, S. (2018). Food safety traits of mussels and clams: distribution of PCBs, PBDEs, OCPs, PAHs and PFASs in sample from different areas using HRMS-Orbitrap and modified QuEChERS extraction followed by GC-MS. Food Additives and Contaminants, 35: 5.

Cheng, H. Y., Ye, R. C. and Chou, C. C. (2003). Increased acid tolerance of Escherichia coli $\mathrm{O} 157: \mathrm{H} 7$ by acid adaptation time and conditions of acid challenge. Food Research International 36: 49 - 56 .

Davidson, P. M. and T. M. Taylor. (2007). Chapter. 33. Chemical preservatives and natural antimicrobial compounds. In Doyle, M. P. and Larry R. Beuchat (eds.), Food Microbiology Fundamentals and Frontiers., 3rd ed. ASM Press, Washington D.C. pp. $713-745$.

Davies, I. C. and Jamabo, N. A. (2016). Determination of mineral contents of edible parts of shellfishes from Okpoka creeks in Rivers State, Nigeria. International Journal of Fisheries and Aquaculture Research, 2 (2): 10 - 18.

Ehigiator, F. A. R. and Akise, O. G. (2016). Proximate, amino acid and mineral composition of wild and cultured fresh water clam (Egeria radiate). Nigerian Journal of Agriculture Food and Environment, 12 (2): 103 - 108.

Ekanem, E. O. and Adegoke, G. O. (1995). Bacteriological study of West African clam (Egeriaradiata Lamarch) and their overlying waters. Food Microbiology, 12: 381 - 385.

Ekpenyong E, Williams I.O, Osakpa U. U. (2013). Variation in the proximate, energy and mineral compositions of different body parts of Macrobrachium macrobranchion (Prawn). Journal of Food Research, 2 (2): 150 - 156.

Etim, L and Brey, T. (1994). Growth, productivity and significance for fishery of the bivalve Egariaradiata (Donacidae) of live bivalve molluscs. pp. 1 - 19.

FDA, (1991). Sanitation of shellfish. growing areas considering and seafood safety (F.E. Ahmed). National Academic Press. Washington DC. Food and Environment, 12 (2): 103 - 108.

Gram, L., Ravn, L. and Rasch, M. 2002. Food spoilage interactions between food spoilage bacteria. International Journal of Food Microbiology, 78: 79-97.

Hatha, A. A. M., Christi, K.C., Singh, R. and Kumar, S. (2005). Bacteriology of the fresh water bivalve clam Batissa violacea (Kai) sold in the Suva Market. The South Pacific Journal of National Science, 23: 48 - 50 .

Holt, J. G., Krieg, N. R., Sneath, P. H. A., Stately, J. T. and Williams, S. T. (1994). St. Bergey's Manual of Determinative Bacteriology (9th Edition). Baltimore, Williams and Wilkins. $787 \mathrm{p}$.

ICMSF International commission on microbiological specificat ions for foods (2005). Microorganisms in Foods. 2nd ed, Kluwer Academic/ Plenum Pub. New York. pp. $84-86$.

Ivon, E. A. and Eyo, V. O. (2018). Proximate composition and mineral contents of edible part of four species of shellfishes from the Calabar River, Nigeria. Annual Research and Review in Biology, 26 (1): 1 - 10.

King, R. P. (2000). Population structure, growth performance and mortality rates of the freshwater clam G. paradoxa Born 1778, in Nun River, Nigeria. Archive of Fisheries and Marine Research, 48(1) :21 - 30 .

Lawrence, T. E., Dikeman, M. E., Stephens, J. W., Obuz, E. and Davis, J. R. (2003). In Situ Investigation of the calciuminduced proteolytic and salting-in mechanisms causing tenderization in calcium-enhanced muscle. Meat Science, 66: $69-75$

Man, C. M. D. (2007). Technological functions of salt in food products. In Kilcast, D and Angus, F (eds). Reducing salt in foods. CRC Press LLC, Boca Raton Fl. pp. 157 - 173.

Mata, L., Vives, M. and Vicente, G. (1994). Extinction of $V$. cholerae in acidic substrata: contaminated fish marinated with lime juice (ceviche). Revista de Biologia Tropical, 42: 479 485.

Moses, S. B. (1990). Growth, biomass, mortality, production and potential yield of the West African clam, Egeria radiata (Lamarck) (Lamellibranchia, Donacidae) in the Cross-River State, Nigeria. Hydrobiologia, 196: 1-15.

Ndelekwute, E. K. and Enyehini, G. E. (2017). Lime juice as a source of organic acids for growth and apparent nutrient digestibility of broiler chickens. Journal of Veterinary Medicine and Surgery, 1: $1-5$.

Odu, N. N., Obafemi, A. and Njoku, H. O. (2010): Comparative assessment of bacteriological quality and proximate composition of laboratory shucked and traditionally shucked tropical periwinkle (Tympanotonus fuscatus). Scientia Africana, 9 (1): 140 - 149.

Okon, M. U., Inyang, C. U. and Akinjogunla, O. J. (2020). Bacterial isolates from bivalve clams $(G$ paradoxa, Born 1778): Occurence, multi-drug resistance, location of antibiotic resistance marker and plasmid profiles. South Asian Journal of Research in Microbiology, 7(3): 35 - 46.

Orjimelukwe, P. C., Ekong, K. S. and Akachukwu, D (2017). Effect of different processing methods on the nutrient composition and sensory properties of E. fimbriata. American Journal of Agricultural Science, 4(5): 107 - 113.

Onyeagba, R. A. and Isu, N. R. (2006). General Microbiology, 2nd (ed) Crystal Publishers, Okigwe Nigeria, 600p.

Oranusi 1, S., Effiong, E. D. and Duru, N. U. (2018). Comparative study of microbial, proximate and heavy metal compositions of some gastropods, bivalve and crustacean seafood. African Journal of Clinical and Experimental 
Microbiology, 19 (4): $291-302$.

Rodrigues, A., Sandstorm, A., Ca, T., Steinsland, H., Jensen, H. and Aaby. P. (2000). Protection from Cholera by adding lime juice to food - results from community and laboratory studies in Guinea-Bissau, West Africa. Tropical Medicine and International Health, 5: 418 - 422.

Samya, H. M. and Mohamed, S. Y. (2006). Proximate evaluation of some economical seafood as a human diet and as an alternative prospective valuable of fish meal. Journal of Fisheries and Aquatic Science. 11 (1): 12 - 27.

Silva, J. G., Morais, H. A. and Silvestre, M. P. C. (2003). Comparative study of the functional properties of bovine globin isolates and sodium caseinate. Food Research International, 36: 73 - 80 .

Simopoulos, A. P. (2003). Importance of the ratio of omega6/omega-3 essential fatty acids: evolutionary aspects. World Review of Nutrition and Dietetics, 92: 1 - 22.

Skrivanova, E., Molatova, M., Houf, K and Marounek, M. (2011). Inhibitory effect of organic acids on Acrobacters in culture and their use for control of Arcobacter butzleri on chicken skin.International Journal Microbiology, 144: 367 371 .
Soyiri, I. N., Agbogh, H. K and Dongdem, Y. T. (2008). A pilot microbial assessment of beef sold in the Ashaiman Market, a suburb of Accra Ghana. Journal of Applied Microbiology. 8: 72 -74 .

Tonbarapagha, K., Douye, V. Z. and Deborah, A. (2018). "Assessing the hygienic status of processed fresh water clam (Galatea paradoxa) in Yenagoa Metropolis, Bayelsa State, Niger Delta, Nigeria." American Journal of Food Science and Technology, 6 (5): 219 - 222.

Udoh, D. I., Udo, I. U. and Udoh, E. I. (2017). Microbiological analysis of the freshwater clam from Cross River, Nigeria. Nigeria Journal of Agriculture, Food and Environment, 13 (3): $59-64$.

Villalobos, L. B. and Elguezabal, L. A. (2001). Microbiological quality of the bivalves Pinctadaimbricate commercialized in Cumana, Venezuela. Food Technology. Acta Cientifica Venezolona, 52: 55 - 61 .

Zhu, Q. and Bai, R. (2007). Comparison of biological characteristics between cultured and wild crab (Eriocheir sinensis) Jiangsu Journal of Agricultural Science, 23: 218 223. unrestricted use, distribution, and reproduction in any medium, provided the original work is cited 